SOY TU HIJO, ENSÉÑAME A VOLAR

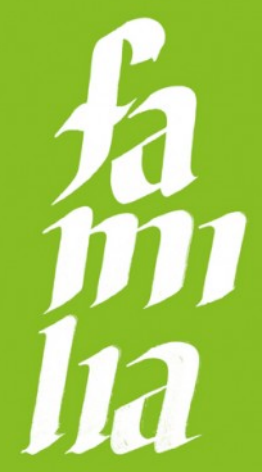

VICTORIA EUGENIA CABRERA GARCÍA

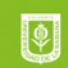

\title{
SOY TU HIJO, ENSÉÑAME A VOLAR
}

Por: Victoria Eugenia Cabrera García

Formato: Impreso

ISBN: 978-958-12-0382-6

Facultad: Instituto de la Familia

Idioma: Español

Precio en dólares: USD $\$ 9,50$

Número de páginas: 112

Palabras clave: Educación en el hogar, Educación para la vida familiar,

Relaciones de pareja

\section{$\$ 25.000$}

\section{Reseña del Producto}

El contenido de este libro está basado en diversos estudios e investigaciones especializadas que la autora ha llevado a cabo en su ejercicio profesional como psicóloga y profesora de aquellos padres que dentro de su misión están comprometidos a trabajar para formar hijos sanos, educados y con un grado de madurez tal que les permita discernir para saber enfrentar la vida. También es resultado de su trabajo en el campo educativo y de las relaciones que, mediante consulta particular, ha tenido con padres y con sus hijos como psicóloga y asesora especializada en las relaciones de familia.

\section{Información Adicional}

Peso: $1 \mathrm{~kg}$

Tamaño: $15 \times 22.5 \times 2 \mathrm{~cm}$

Sku: 9789581203826

Código topografico: 306.87

\section{Tabla de contenido}

\section{PALABRAS PRELIMINARES}

PRÓLOGO

CAPÍTULO I. La misión de ser esposos: la preparación para una relación de pareja y el reto de enfrentar y superar los conflictos

La satisfacción de vivir en pareja

La visión de los especialistas

Un buen comienzo para las relaciones entre esposos está en el significado que le demos a la palabra calidad

Y ¿qué pasa con los momentos de tristeza y de angustia? ¿Con aquellas situaciones que deprimen, agobian y bajan la autoestima?

Conflictos entre esposos... ¿naturales?

¿Y cómo resolver los conflictos sin fallar en el intento? 
Un NO rotundo a la imposición dominante

¿Y qué dicen los especialistas?

Varias ideas que pueden ayudar en la resolución de un conflicto

Diez razones para evitar alterarse

¿Está dispuesto a dialogar?

CAPÍTULO II. La tarea de los padres: la alegría de ser papá, de ser mamá y el reto de enfrentar y superar situaciones estresantes La satisfacción de ser padres

¿Qué ocurre cuando pretende "ser amigo" de los hijos?

¿Y existen los padres ideales?

Rompa el hielo

Lo fundamental de la figura paterna

Lo fundamental de la figura materna

Entonces, papá y mamá

Y si los padres son separados

Y si debió asumir sola(o) la educación de sus hijos

CAPÍTULO III. Cuando tenemos momentos difíciles

¿Y si es hijo único?

La misión: educar en tiempos de hoy

La mirada de los especialistas

¿Pero entonces, cómo definir el estrés de los padres?

¿Y cómo hacerle frente a esos momentos críticos?

Padres actualizados, son padres en la jugada

CAPÍTULO IV. Separado(a), ¿y mis hijos qué?

¿Qué pasa si es usted quien no vive con su hijo?

CAPÍTULO V. ¿Y si soy madre soltera o padre soltero?

CAPÍTULO VI. ¿Estoy haciendo bien la tarea? Guía práctica para responder a esta pregunta

¿Cómo está su relación con los hijos?

Tener un hijo, qué gran satisfacción

¡Estamos embarazados!

La mirada de los especialistas

Compromiso de los padres, espejo para los hijos

Juventud, ¡divino tesoro!

¿Y qué pasa con los hijos si muere alguno de los padres?

Monitoreo, supervisión o control

Apoyo y aceptación, sinónimos de comprensión y respaldo

El control psicológico no es una opción

El trato rudo, totalmente descartado

¿Cómo le enseño a mi hijo a enfrentar la vida? 